\title{
MEMAKNAI SIKAP INTEGRITAS AKUNTAN PUBLIK DI KAP "CEMERLANG" SURABAYA (STUDI FENOMENOLOGI)
}

\author{
Ratna Anggraini Aripratiwi, Unti Ludigdo, M. Achsin \\ Program Pasca Sarjana Universitas Brawijaya Malang \\ Jl. MT. Haryono 165 Malang \\ e-mail: ratnaanggraini.ra@gmail.com
}

\begin{abstract}
This study aims to explore the deep meaning of integrity attitudes experienced, felt, and run by public accountants in one of the famous KAP in Surabaya, KAP "Cemerlang".Revealing the attitude of the integrity of public accountants because of the many public accountants are still dragged into fraud and violations, resulting in unethical decisions. Every public accountant has a different perspective in determining and exercising an attitude of integrity, whether to defend or even take it off for a particular purpose. And in the end bring up a variety of diverse meanings of pure integrity and pragmatic integrity.
\end{abstract}

Keywords: Integrity, phenomenology, public accountant.

\section{PENDAHULUAN}

Berkembangnya profesi akuntan khususnya akuntan publik dalam suatu negara sejalan dengan berkembangnya bisnis di negara tersebut. Pada profesi akuntan inilah banyak pihak menggantungkan harapan besar atas bisnis yang sehat, sebut saja kreditur, investor, pemerintah, dan masyarakat. Harapan penilaian kondisi ekonomi dari sebuah korporasi yang transparan dan tidak memihak kepentingan pihak tertentu. Profesi akuntan publik sendiri memiliki tanggung jawab untuk menaikkan tingkat keandalan laporan keuangan sehingga masyarakat memperoleh informasi keuangan yang andal sebagai dasar untuk memutuskan alokasi sumber ekonomi (Nasirwan, 2011), semakin berkembangnya globalisasi dan diversifikasi jasa akuntan disertai dengan kombinasi pasar yang semakin kompetitif menyebabkan perhatian lebih ditujukan kepada profesi akuntan dan standar etisnya (Leung dan Cooper, 2005 dalam Jackling, 2007).

Selain itu, berbagai skandal yang menimpa dunia bisnis dan menyeret profesi akuntan telah membuat publik terhenyak. Sebut saja kasus fenomenal Enron dan KAP “Arthur Andersen”, Worldcom, Kmart Corp., dan sederet namaperusahaan raksasa lainnya yang ikut runtuh setelah runtuhnya Enron. Kemudian beberapa kasus yang di Indonesia seperti kasus PT Kimia Farma atas mark up laba perusahaan, kasus Bapepam LK yang menemukan banyaknya pelanggaran Standar Akuntansi Keuangan (SAK) pada laporan keuangan 2010 yang dilakukan oleh perusahaan-perusahaan go public dimana mereka memperoleh opini WTP dari akuntan publiknya, kasus kredit fiktif yang menimpa BRI atas debiturnya raden motor serta melibatkan akuntan publik yang melakukan audit atas Raden Motor, dan kasus terbaru di 2017 dimana terjadi kegagalan audit pada PT Indosat oleh KAP Ernst \& Young Indonesia.

Skandal-skandal yang terjadi membuktikan satu hal bahwa betapa mudahnya para pebisnis menipu dengan modal kecantikan laporan keuangan. Akuntan

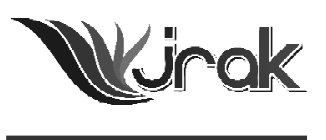

Jurnal Reviu Akuntansi dan Keuangan ISSN: 2088-0685 Vol. 7 No. 1, April 2017 Pp 993-1002 
Memaknai Sikap

Integritas...

994 yang notabene-nya memiliki peran penting dalam dunia bisnis justru saat ini disebut sebagai pelanggeng adanya pelanggaran etis, bahkan akuntan disebutsebut sebagai pelanggeng kapitalisme atau sebagai subsistem dari ideologi kapitalisme yang mengutamakan kepentingan pihak pemilik modal (Harahap dalam Nasirwan, 2011). Karena di dunia akuntansi sendiri tidak sedikit skandal yang telah terjadi baik itu di lingkungan bisnis maupun di lingkungan akuntan publiknya. Yang semakin membuktikan bahwa mungkin tidak hanya dorongan dari dalam diri akuntan saja yang membuat penyimpangan perilaku akuntan melainkan adanya dorongan kuat dari lingkungan eksternal yang tidak kondusif. Sampai pada akhirnya memunculkan opini bahwa akuntan pada saat ini dianggap sebagai sebuah kelompok yang memiliki tingkat pemikiran moral yang lebih rendah dibandingkan kelompok profesi lainnya (Eynon et al., dalam McPhail dan Walters, 2009). Sungguh miris mendengar ungkapan tersebut.

Jackling et al. (2007) menyatakan bahwa kolapsnya sebagian perusahaan raksasa seperti Enron, WorldCom, HIH Insurance, atau Parmalat telah menyebabkan hilangnya kepercayaan publik. Sedangkan menurut Fearnley et al. (2005) bahwa kolapsnya Enron dan Arthur Andersen menunjukkan efek yang merugikan bagi kantor akuntan yaitu hilangnya tingkat kepercayaan atas integritas kantor akuntan tersebut. Kasus tesebut bahkan membuat hilangnya kepercayaan publik atas nilai-nilai etis pada KAP yang terkait langsung dengan skeptisisme atas independensi KAP dan akuntan profesional (Fearnley, Beattie, dan Brandt 2005 dalam Azis et al., 2015).

Banyak faktor yang membuat akuntan publik terseret dalam derasnya aliran kecurangan dan pelanggaran dan menghasilkan keputusan yang tidak etis, yang salah satu faktornya adalah karena tekanan ketaatan (Nadirsyah dan Malahayati, 2007). Studi yang dilakukan oleh Goldman dan Barlev (1974) dalam Azis et al., (2015) menujukkan bahwa KAP besar pun tak kuasa menahan tekanan yang dilakukan oleh klien, seperti skandal yang terjadi pada Enron dan sejumlah kasus lain.

Apabila kita mengevaluasi fenomena ketidakberesan praktik akuntan publik khususnya yang terjadi di Indonesia, tekanan inilah yang menjadi salah satu penyebab terjadinya kegagalan audit. Seringkali auditor atau akuntan publik mengalami dilema etis yang melibatkan nilai-nilai yang bertentangan dengan standar etika profesi yang akhirnya melunturkan prinsip etis yang seharusnya diemban yaitu salah satunya integritas. Integritas menjadi salah satu prinsip etis yang utama yang wajib dipahami dan dilaksanakan oleh setiap akuntan. Apabila kita menilik kembali pengertian integritas di dalam kamus, kita akan menemukan makna bahwa integritas merupakan suatu misi atau tujuan bersama untuk tumbuh dan berkembang sesuai hati nurani setiap individu.

Tingkat kepercayaan publik kepada kinerja auditor tidak hanya bertumpu pada cara kerja dan keahliannya saja melainkan juga pemahaman etika yang dimiliki oleh auditor (Nadirsyah dan Malahayati, 2007). Sehingga nilai-nilai etis yang terdiri dari prinsip etis dan aturan etika perlu serta wajib dipahami oleh setiap profesi akuntan dalam menjalankan tugas keprofesiannya, tak hanya sebagai simbol dalam suatu organisasi saja dan pelanggaran etika lebih lanjut oleh akuntan publik dapat diminimalisasi dengan baik.

Menggarisbawahi penjelasan diatas maka penulis menganggap perlu untuk mengangkat masalah fenomena integritas yang dikhawatirkan semakin kritis dan hilang dari setiap individu khususnya bagi profesi akuntan. Profesi akuntan yang diharapkan mampu menjadi solusi atas krisis etika dan bisnis yang terjadi, bukan hanya dipandang sebagai bagian dari krisis itu sendiri. Dengan memaknai secara mendalam bagaimana sebenarnya makna dari integritas itu di mata akuntan profesi, maka diharapkan ke depannya akuntan dapat mengembalikan citra positif dari profesi akuntan. 
Penelitian ini menggunakan paradigma konstruktivisme. Paradigma konstruktivisme meneguhkan asumsi bahwa individu-individu selalu berusaha memahami dunia dimana mereka hidup dan bekerja, mengembangkan berbagai makna subyektif berdasarkan pengalaman mereka (Creswell, 2013:11). Dalam pandangan konstruktivisme, seorang peneliti diarahkan untuk mencari makna atas realitas yang terjadi dalam lingkungan sosial dengan mengandalkan berbagai pendapat dari partisipan yang masuk dalam lingkungan sosial tersebut.

Terdapat beberapa tahapan dalam penelitian fenomenologi yaitu epoche, reduksi fenomenologi, variasi imajinasi, dan sintesis makna dan esensi. Tahap pertama yaitu Epoche, yang berarti "menunda putusan" atau "mengosongkan diri dari keyakinan tertentu". Epoche adalah sebuah proses dimana peneliti menangguhkan terlebih dahulu penilaian terhadap fenomena yang diamatinya walaupun ia telah memiliki prakonsepsi tersendiri terhadap fenomena tersebut. Peneliti dituntut untuk menghilangkan sementara masalah penilaian maupun pertimbangan awalnya sehingga dapat diperoleh pemahaman baru tentang obyek penelitian berdasarkan persepsi dari informan, sehingga fenomena tersebut mampu berbicara apa adanya.

Tahap kedua adalah reduksi fenomenologi, dimana tahap untuk memahami fenomena yang muncul melalui pemahaman atas ungkapan-ungkapan atau ekspresi-ekspresi yang dimunculkan oleh subyek. Terdapat beberapa tahapan yang dilakukan yaitu horizonalizing dan cluster of meaning. Tahap horisonalisasi data (horizonalizing) yaitu merinci setiap pernyataan yang muncul dengan tidak melakukan pengulangan pernyataan agar tidak tumpang tindih. Selanjutnya pernyataan tersebut dikelompokkan ke dalam tema-tema atau unit-unit yang bermakna (meaning unit) disertai dengan penjelasan secara tekstural (textural description) dari setiap makna yang muncul. Dan apabila disimpulkan bahwa proses reduksi fenomenologi adalah prosedur metodik dimana kita meningkatkan pengetahuan kita dari level fakta ke level ide atau esensi.

Langkah ketiga adalah variasi imajinasi yaitu mencari makna-makna yang mungkin dengan memanfaatkan imajinasi peneliti (Kuswarno, 2009:52). Tujuan dari variasi imajinasi adalah mencapai deskripsi struktural (structural descriotion) dari sebuah pengalaman yaitu bagaimana fenomena itu berbicara mengenai dirinya. Target akhir dari variasi imajinasi adalah makna yang murni yang dipengaruhi oleh intuisi kita sebagai peneliti. Langkah terakhir adalah sintesa makna dan esensi yaitu membangun keseluruhan deskripsi dari sebuah peristiwa atau fenomena. Integrasi intuisi dasar-dasar deskripsi tekstural dan struktural ke dalam satu pernyataan yang menggambarkan hakikat dari fenomena secara keseluruhan. Sehingga tahap ini adalah tahap penegakan pengetahuan mengenai hakikat. Menurut Husserl, esensi adalah sesuatu yang umum dan berlaku universal dan tidak pernah terungkap secara sempurna.

Berikut adalah model penelitian fenomenologi khususnya fenomenologi transendental dari Husserl yaitu: 


\section{Memaknai Sikap \\ Integritas...} 996

Gambar 1: Model Penelitian Fenomenologi

Gambar 2: A Data Collection Circle (Lingkaran Pengumpulan Data)

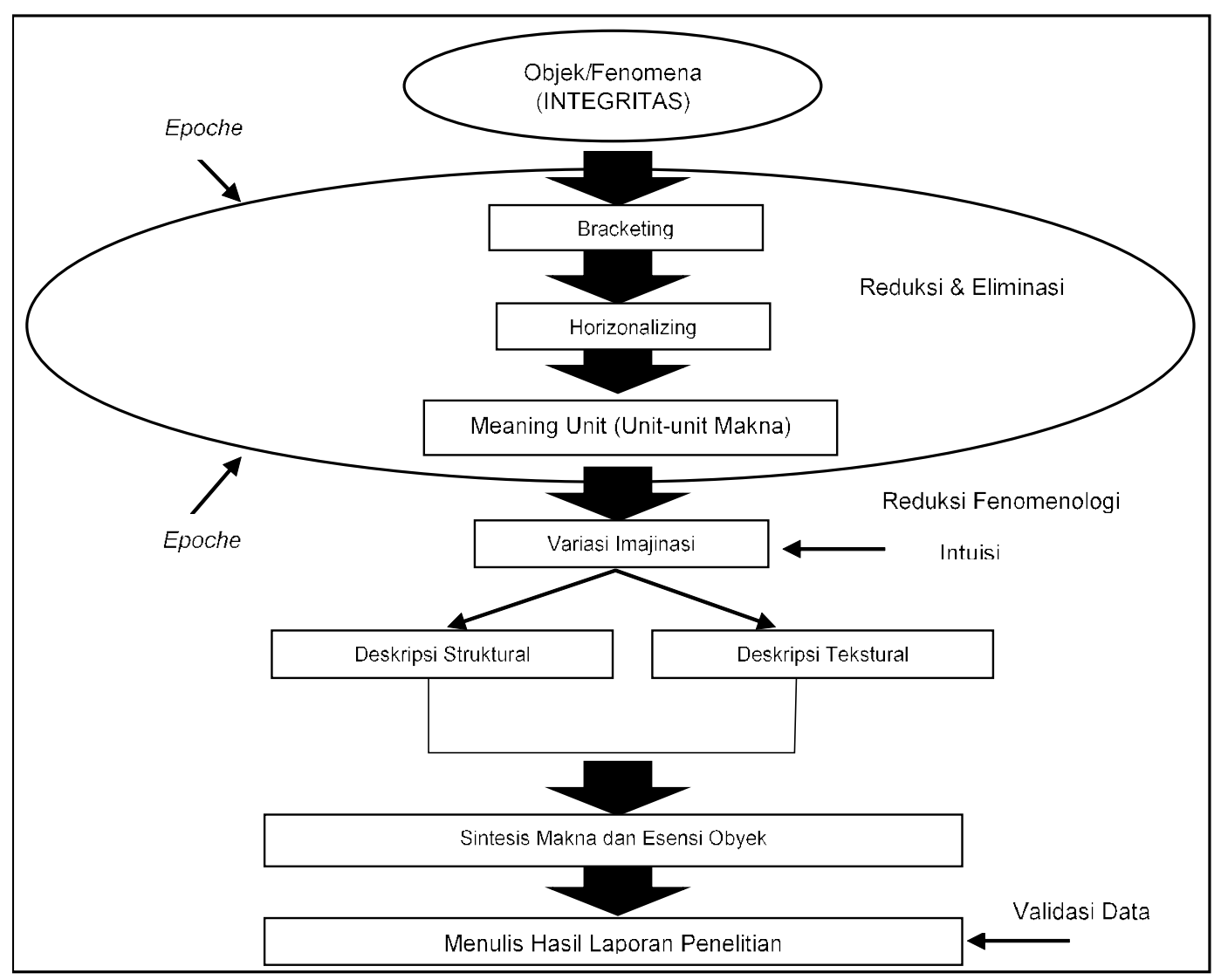

Sumber Kuswarno (2009:80)

Dengan teknik pengumpulan data yang benar dan tepat akan menghasilkan data yang mempunyai tingkat kredibilitas tinggi atau bahkan sebaliknya. Pada penelitian fenomenologi terdapat tiga teknik pengumpulan data yaitu observasi, wawancara mendalam, dan telaah dokumen. Namun teknik utama pengumpulan data pada penelitian fenomenologi adalah wawancara mendalam. Melalui wawancara mendalam maka akan diperoleh esensi dari fenomena yang diamati dan diceritakan dari sudut pandang orang yang mengalaminya secara langsung. Sebagai acuan pengumpulan data yang digunakan oleh peneliti adalah teknik pengumpulan data dari Cresswell (1998: 110) yang dikenal sebagai "A Data Collection Circle"yaitu sebagai berikut:

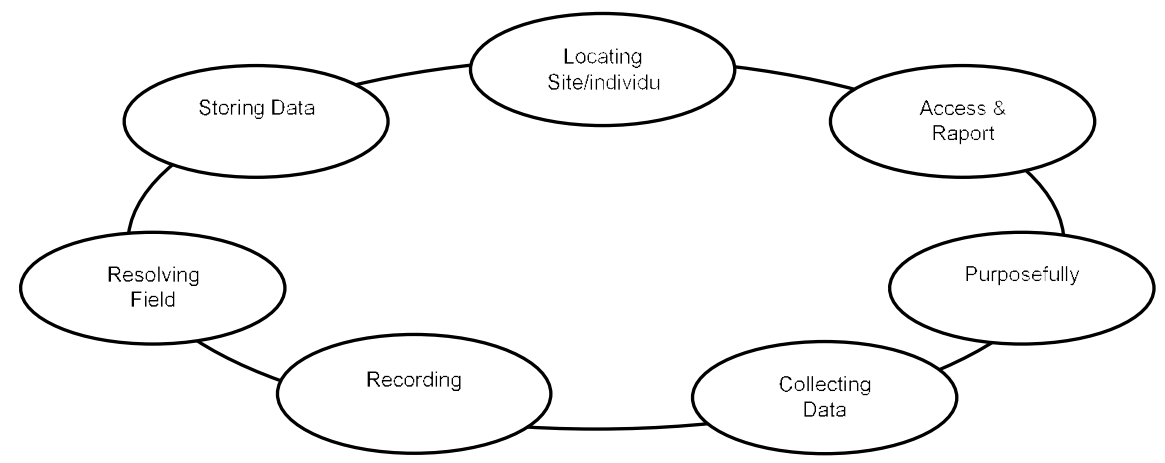

Sumber: Cresswell (1998:110)

Setelah seluruh data diperoleh, selanjutnya yang dilakukan adalah menganalisa data sehingga diperoleh esensi murni dari fenomena yang diteliti. Karena data penelitin ini berupa data kualitatif, maka menurut Kuswarno (2009:136) terdapat tiga alur kegiatan yang dapat dilakukan secara bersama yaitu reduksi 
data, penyajian data, dan penarikan kesimpulan atau verifikasi. Menurut Mulyana (2001:20), reduksi data adalah proses pemilihan, pemusatan perhatian, pengabstrakan dan transformasi data kasar yang muncul dari catatan-catatan yang tertulis di lapangan. Data kualitatif yang diperoleh selama penelitian ditransformasikan dengan berbagai cara seperti seleksi yang ketat, ringkasan, atau uraian singkat, serta penggolongan dalam suatu pola yang lebih kuat.

Setelah data diperoleh, dianalisis, dan ditarik kesimpulan makna, maka selanjutnya peneliti melakukan uji keabsahan data. Pemeriksaan keabsahan data tersebut bertujuan untuk menguji kesahihan dan keandalan data serta tingkat kepercayaan atas data tersebut. Dengan dilakukannya uji keabsahan data maka akan mengurangi risiko kesalahan yang akan timbul. Sehingga dapat dikatakan bahwa validitas dan reliabilitas data yang diperoleh harus diuji melalui teknik pemeriksaan keabsahan data. Keabsahan data atau validasi data menurut Cresswell (1998:207-208) dilakukan melalui verifikasi data oleh peneliti luar.

\section{HASIL DAN PEMBAHASAN}

Penelitian ini dilakukan di KAP "Cemerlang" dengan 7 orang partisipan. Seluruh partisipan adalah akuntan publik yang telah bersertifikasi CPA (Certified Publik Accountant) dan telah berprofesi sebagai akuntan publik lebih dari 3 tahun. Dari 7 partisipan tersebut, diperoleh dua kategori atau tema utama atas makna sikap integritas akuntan publik, yaitu integritas murni dan integritas pragmatis. Berikut adalah hasil analisa data yang diperoleh dan memunculkan tematema umum (level 3):

\begin{tabular}{|c|c|c|}
\hline Level 1 & Level 2 & Level 3 \\
\hline Menolak black bonus atau unprofessional fee & \multirow{3}{*}{$\begin{array}{l}\text { Tegas menolak } \\
\text { permintaan } \\
\text { klien }\end{array}$} & \multirow{30}{*}{$\begin{array}{l}\text { Integritas } \\
\text { Murni }\end{array}$} \\
\hline Menolak order tujuan tertentu & & \\
\hline Menolak negosiasi opini dan temuan signifikan & & \\
\hline Tidak takut kehilangan klien & \multirow{3}{*}{ Sikap berani } & \\
\hline Tidak takut diancam klien & & \\
\hline Tidak takut pemutusan perikatan & & \\
\hline Pemutusan kontrak perikatan & \multirow{7}{*}{$\begin{array}{l}\text { Akibat sikap } \\
\text { berani dan tegas }\end{array}$} & \\
\hline Penyebaran negative issu oleh klien & & \\
\hline Dilaporkan kepada owner KAP & & \\
\hline Memperoleh kepercayaan banyak pihak & & \\
\hline Memperoleh nama baik & & \\
\hline Audit berkualitas & & \\
\hline Kehormatan terjaga & & \\
\hline Menyampaikan temuan dengan jujur & \multirow{2}{*}{$\begin{array}{l}\text { Sikap jujur dan } \\
\text { apa adanya }\end{array}$} & \\
\hline Menyampaikan hasil audit apa adanya & & \\
\hline Bekerja dengan jujur & \multirow{8}{*}{$\begin{array}{l}\text { Prinsip jujur } \\
\text { dan amanah } \\
\text { sesuai kaidah } \\
\text { agama }\end{array}$} & \\
\hline Bekerja adalah ibadah & & \\
\hline Bekerja untuk keluarga & & \\
\hline Bekerja dengan kaidah agama & & \\
\hline Spiritual dan agama harus seimbang & & \\
\hline Selalu ingat Tuhan & & \\
\hline Rejeki diatur oleh Allah & & \\
\hline Tahan terhadap godaan materi & & \\
\hline Negosiasi temuan dan opini dengan klien & \multirow{3}{*}{$\begin{array}{l}\text { Sikap tidak } \\
\text { tegas }\end{array}$} & \\
\hline Bersikap fleksibel dan tidak kaku & & \\
\hline Mengikuti keinginan klien & & \\
\hline Bekerja berdasarkan target bisnis & \multirow{4}{*}{$\begin{array}{l}\text { Sikap } \\
\text { pragmatisme } \\
\text { bisnis }\end{array}$} & \\
\hline Bekerja berdasarkan nilai materi & & \\
\hline Omset meningkat & & \\
\hline Memberikan manfaat bagi tim dan KAP & & \\
\hline
\end{tabular}




\section{Memaknai Sikap \\ Integritas...}

998

Tabel 1

Pengelompokan

Tema-Tema Umum (Cluster of Meaning)

\begin{tabular}{|c|c|c|}
\hline $\begin{array}{l}\text { Lingkungan tidak kondusif akibat target } \\
\text { marketing yang berat }\end{array}$ & \multirow{6}{*}{$\begin{array}{l}\text { Penyebab sikap } \\
\text { pragmatisme } \\
\text { bisnis }\end{array}$} & \multirow{10}{*}{$\begin{array}{l}\text { Integritas } \\
\text { Pragmatis }\end{array}$} \\
\hline Tidak tahan godaan materi & & \\
\hline Target marketing berat & & \\
\hline Persaingan antar KAP sangat ketat & & \\
\hline Banyak godaan materi & & \\
\hline Klien repeat order & & \\
\hline $\begin{array}{l}\text { Melakukan audit kilat tanpa prosedur audit } \\
\text { lengkap }\end{array}$ & \multirow{4}{*}{$\begin{array}{l}\text { Akibat sikap } \\
\text { pragmatisme } \\
\text { bisnis }\end{array}$} & \\
\hline Mengabaikan program audit & & \\
\hline Menerima order dengan tujuan tertentu & & \\
\hline Mengikuti keinginan klien & & \\
\hline $\begin{array}{l}\text { Menjalankan audit berdasarkan prosedur dan } \\
\text { program }\end{array}$ & \multirow{2}{*}{$\begin{array}{l}\text { Melaksanakan } \\
\text { sikap tegas }\end{array}$} & \multirow{8}{*}{$\begin{array}{l}\text { Integritas } \\
\text { Pragmatis } \\
\text { Kontem- } \\
\text { porer }\end{array}$} \\
\hline $\begin{array}{l}\text { Menolak negosiasi yang bertentangan dengan } \\
\text { standar }\end{array}$ & & \\
\hline $\begin{array}{l}\text { Akuntan publik adalah karyawan KAP yang } \\
\text { harus patuh pada aturan KAP }\end{array}$ & \multirow{2}{*}{$\begin{array}{l}\text { Dilema } \\
\text { kepentingan }\end{array}$} & \\
\hline Mempertaruhkan going concern di KAP & & \\
\hline Mengikuti keputusan otoritas tertinggi & \multirow{4}{*}{$\begin{array}{l}\text { Intervensi owner } \\
\text { dan pihak } \\
\text { berelasi }\end{array}$} & \\
\hline Intervensi pihak berelasi & & \\
\hline Lingkungan tidak kondusif akibat pihak berelasi & & \\
\hline Integritas terasa asing oleh akuntan publik & & \\
\hline
\end{tabular}

\section{Kemurnian Sikap Integritas}

Kategori integritas murni muncul sebagai hasil sintesa makna atas setiap perilaku yang ditunjukkan, dilaksanakan, dan dirasakan oleh para partisipan. Terdapat tiga partisipan pada kategori ini yang menjalankan integritas secara murni, holistik, berdasarkan aturan yang berlaku, nilai-nilai agama dan spiritual. Dan tak hanya menjalankan, namun telah dipatri dalam hati dan menjadikan integritas sebagai pondasi. Para partisipan menanamkan dasar atau pondasi terlebih dahulu, sehingga nantinya fokus para partisipan adalah sikap integritas yang benar-benar murni. Setiap akuntan publik memiliki alasannya tersendiri dalam bersikap. Alasan adalah sebuah keputusan awal seorang akuntan publik dalam bersikap dan bekerja. Alasan yang muncul akan menentukan nilai dari setiap individu, bagaimana nantinya ia akan menjalankan tugas keprofesiannya, mengambil keputusan, dan berinteraksi dengan lingkungan sekitar. Apabila dilihat pada kategori integritas murni, alasan yang mendasari partisipan adalah sikap non materialistik, tegas, berani, dan mengutamakan kejujuran dan amanah.

Akuntan publik yang masuk dalam identitas ini adalah mereka yang selalu memikirkan akibat yang akan muncul apabila seorang akuntan publik tidak menjalankan sikap integritas secara holistik, utuh, dan apa adanya. Hal tersebut yang mendorong setiap akuntan publik harus menetapkan prinsip, standard, atau pondasi yang kuat, agar akibat yang nantinya terjadi dapat dihindari atau diantisipasi. Mereka memberi alasan 'pondasi' sejak pertama berkecimpung ke dalam dunia profesi akuntan. Dengan ditetapkannya sebuah prinsip, maka diharapkan segala gangguan, akibat-akibat, atau masalah yang muncul di kemudian hari atau di masa yang akan datang dapat menjadi benteng pertahanan bagi sikap integritas mereka. Prinsip yang mereka tanamkan adalah prinsip amanah dan kejujuran. Amanah dalam mengemban tugas karena mereka memiliki tanggung jawab profesi untuk kepentingan umum, dan untuk menjalankan amanah tersebut maka diperlukan sikap jujur sebagai landasan utama dalam bertindak, berperilaku, berkata, maupun berpendapat.

Mereka menetapkan nilai-nilai agama sebagai pondasi perilaku. Dengan nilai-nilai yang mereka tanamkan akan berimbas pada perilaku mereka sehari- 
hari, bagaimana mereka berinteraksi dengan kehidupan sosial mereka, dan bagaimana mereka mengambil keputusan. Pada hasil akhirnya akan menunjukkan bahwa mereka menjalankan tugas keproesiannya dengan sepenuh hati, amanah pada tanggung jawabnya, dan mencapainya dengan cara kejujuran.. Mereka melaksanakan prinsip integritas karena adanya kebiasaan, prinsip, nilai, dan tradisi. Mereka sudah biasa melakukan setiap tugas keprofesiannya dengan penuh integrity, tak pandang bulu, apa adanya, menyampaikan seluruhnya dengan penuh kejujuran, dan amanah. Prinsip yang mereka tanamkan sebagai pondasi dan benteng pertahanan adalah sikap jujur dan amanah. Ketika prinsip tersebut terus dilakukan dan menjadi habit dalam berprofesi maka akan muncul sebuah tradisi integritas yang baik.

\section{Pragmatisme Bisnis Mengabaikan Sikap Integritas}

Pada kategori lainnya yang muncul adalah integritas pragmatis dan integritas kontemporer. Peneliti lebih menggabungkan kedua kategori ini dikarenakan kedua kategori ini memiliki pola alasan yang serupa yaitu sikap pragmatis. Munculnya dilema etis tersebut dikarenakan pada kategori integritas pragmatis, terdapat target marketing yang berat dan cukup mencekik para partisipan sehingga mendorong fokus perilaku partisipan untuk lebih mementingkan sikap materialistiknya daripada mempertahankan nilai etika. Terdapat unsur uang, bisnis, order, target pekerjaan, atau bahkan keberlangsungan hidup yang menjadi tolak ukur seseorang dalam bekerja, bertindak, maupun mengambil keputusan. Diawal menjalankan praktik profesi mereka fokus pada target bisnis yang diberikan oleh KAP kepada masing-masing CPA atau partner audit. Target bisnis atau order mencapai Rp3,5M per tahun untuk setiap partner. Dari situ mereka menetapkan standar mereka, bagaimana mereka akan bekerja, bertindak, berperilaku, dan mengambil keputusan, akan disesuaikan dengan fokus awal mereka. Prioritas utama seorang akuntan publik adalah mencapai target bisnis yang telah ditetapkan oleh pihak kantor akuntan publik. Lebih lanjut disampaikan bahwa adanya unsur reward and punishment pula pada KAP tempat mereka bernaung apabila target tersebut telah dicapai. Reward yang didapat tentunya pendapatan yang diperoleh semakin banyak, bonus pun ikut mengalir searah meningkatnya pendapatan masingmasing akuntan publik. Sedangkan punishment yang diperoleh jelas adalah potongan gaji atau bahkan tidak digaji.

Bagi para partisipan kategori ini, materi adalah ukuran kesuksesan mereka. Apabila target mereka tercapai, omset meningkat, pekerjaan selesai dilakukan, dan mencapai keuntungan, maka dikatakan mereka telah sukses dalam melaksanakan tugas keprofesian mereka. Dan untuk mencapai kesuksesan tersebut tak jarang sikap integritas mereka juga ditentukan oleh materi. Ketidakjujuran dalam bekerja, tidak sepenuhnya amanah dalam melaksanakan tugas profesinya, atau bahkan merambah pada unsur fraud. Adanya 'motif untuk' atau 'tujuan' tertentu oleh akuntan publik dalam menjalankan prinsip integritas yaitu mencapai kesuksesan materi. Pragmatisme bisnis yang diterapkan oleh akuntan terbukti telah mampu menjadi kekuatan yang menopang tindak dan sikap para informan dalam memahami praktik integritas saat penugasan audit. Pragmatisme ini dianggap sebagai kekuatan yang membentuk pola pikir pragmatis ketika para informan mengalami dilema etis.

Dilema etis selanjutnya yaitu non materi dan materi, apa yang harus diutamakan atau dinomorsatukan. Kontemporer artinya mengikuti perkembangan kebutuhan yang bersifat kekinian, sementara, atau jangka pendek. Contohnya adalah ketika partisipan mengatakan tentang mempertaruhkan keberlangsungan atau going concern nya di KAP "Cemerlang". Mereka yang hanya berstatus pegawai atau karyawan KAP, pada akhirnya harus mengikuti aturan yang ada di KAP termasuk mengikuti perintah owner, walaupun perintah tersebut justru mengabaikan sikap-sikap integritas partisipan. Terdapat 2 akuntan publik yang mengemukakan bahwa dalam melaksanakan tugas keprofesiannya, muncul 
Memaknai Sikap

Integritas...

1000 problema antara alasan mereka bertindak. Di satu sisi mereka telah melaksanakan prinsip integritas secara konsisten, apa adanya, dan sesuai aturan, namun di sisi lain mereka tidak mampu berkutik ketika ada faktor pendorong yang menyebabkan mereka akan menomorsatukan alasan materi.

Para partisipan melaksanakan tugas keprofesiannya sesuai dengan standar yang berlaku, berupaya jujur, amanah dalam menjalankan tugas. Mereka memahami sekali bagaimana seorang akuntan publik harus mempertahankan prinsip integritasnya, karena integritas adalah pola dasar yang akan menggiring seseorang akan menerapkan prinsip etis lainnya. Namun ketika mereka dipertemukan dengan suatu kondisi lingkungan mereka yang otoriter, dimana adanya intervensi kepemimpinan dari pihak owner dan klien, mereka tak mampu mempertahankan prinsip integritas mereka. Hal tersebut dikarenakan adanya alasan materi yaitu keberlangsungan hidup atau pekerjaan mereka di KAP "Cemerlang".

Banyak faktor yang membuat akuntan publik terseret dalam derasnya aliran kecurangan dan pelanggaran, yang menghasilkan keputusan yang tidak etis yang salah satu faktornya adalah tekanan ketaatan (Nadirsyah dan Malahayati, 2007). Dan studi yang dilakukan oleh Goldman dan Barlev (1974) dalam Azis et al., (2015) menunjukkan bahwa KAP besar pun tak kuasa menahan tekanan yang dilakukan oleh klien, seperti skandal yang terjadi pada Enron dan sejumlah kasus lain. Hal itu pula yang dialami oleh partisipan kategori pragmatis kontemporer. Adanya tekanan yang muncul dari lingkungan yang menyebabkan harus mengabaikan sikap integritas yang sebenarnya.

Dari situ terlihat bahwa ada dominasi sikap pragmatisme bisnis akuntan publik ketika menentukan sikap integritas dan mempengaruhi perilaku mereka sehari-hari. Pragmatisme adalah aliran filsafat yang mengajarkan bahwa yang benar adalah segala sesuatu yang membuktikan dirinya sebagai yang benar dengan melihat kepada akibat-akibat atau hasilnya yang bermanfaat secara praktis. Mereka merasa telah melakukan hal yang benar menurut standard mereka karena adanya manfaat atau keuntungan yang mereka berikan sebagai hasil perilaku mereka. Fenomena integritas yang muncul dalam pikiran akuntan publik selalu bersifat pribadi dan bukan merupakan fakta-fakta umum.

Selain itu akibat pragmatisme bisnis, terdapat akibat lainnya yang menyebabkan terasingnya sikap integritas yaitu intervensi pihak berelasi pada sikap akuntan publik. Akuntan publik pada sub kategori ini menunjukkan akuntan publik yang lebih mengutamakan motif jangka pendek, temporer, atau saat ini saja. Yang ada dalam benak mereka adalah yang penting tidak terdapat unsur fraud, kelangsungan bisnis di KAP berjalan lancar, dan tidak mengganggu going concern akuntan publik di KAP. Pada dasarnya mereka adalah homo economicus yang selalu mempertimbangkan segala sesuatu berdasarkan nilai ekonomi dan materi dari setiap tindakan yang dilakukan. Mereka melaksanakan prinsip integritas dengan baik, namun karena munculnya intervensi dari pihak tertentu menyebabkan mereka harus mengalah karena alasan yang bersifat sementara. Adanya konsekuensi yang akan mengganggu going concern mereka sebagai akuntan publik apabila tidak mengikuti budaya atau lingkungan sosialnya.

\section{SIMPULAN}

Kerentanan profesi akuntan ikut terseret dalam arus globalisasi juga dipengaruhi oleh sikap integritas yang ditentukan oleh setiap akuntan publik. Bagaimana arah sikap mereka nantinya, keputusan yang diambil, akan bergantung dari pondasi awal yang ditentukan oleh setiap individu. Adanya alasan material dan non material sebagai keputusan pertama seseorang menjalani sikap integritas, alasan mana yang akan menjadi alasan utamanya. Alasan tersebut yang akan mendorong seseorang dalam bersikap, sehingga pada akhirnya memunculkan sebuah kategori seorang individu yang berintegritas atau tidak. 
Dari alasan tersebut yang memunculkan kategori sikap integritas yaitu integritas murni dan integritas pragmatis. Integritas murni menunjukkan sikap yang ditunjukkan oleh akuntan publik dengan mempertahankan sikap integritasnya secara holistik, jujur, apa adanya, dan berdasarkan standar yang berlaku. Mereka mengedepankan sikap amanah atas tugas yang dijalankan. Sikap yang mengutamakan kepentingan umum atau publik, dengan menetapkan pondasi agama, spiritual religiusitas, dan ketuhanan.

Sedangkan integritas pragmatis menunjukkan pengabaian pada sikap integritas. Para partisipan lebih mengutamakan faktor ekonomi, target bisnis, materi, jabatan, serta mengutamakan kepentingan tertentu dalam berprofesi. Fokus yang mereka tanamkan adalah sikap pragmatis, yaitu mereka menganggap apa yang mereka lakukan adalah hal yang benar karena telah memberikan manfaat. Manfaat yang digarisbawahi adalah peningkatan bisnis KAP dan keuntungan yang diperoleh, dengan mengabaikan sikap integritas murni. Pragmatis juga mendorong seseorang untuk lebih mengutamakan kepentingan pihak tertentu yaitu klien dan owner dalam menjalin hubungan istimewa. Para partisipan lebih mementingkan jabatan dan keberlangsungannya di KAP "Cemerlang". Dalam kategori ini, lebih menekankan adanya tekanan ketaatan yaitu tekanan seseorang untuk mementingkan kepentingan pribadi dibandingkan kepentingan umum atau publik.

Sikap integritas yang dimaknai oleh akuntan publik akan menentukan arah sikap mereka dalam bertugas dan keputusan etis yang akan diambil, apakah akan tetap mempertahankan atau mengabaikannya. Dengan pemahaman yang mendalam secara holistik dan berlandaskan pada pondasi agama, norma, dan standar yang berlaku akan menggiring akuntan publik pada sikap integritas murni berdasarkan akhlakul karimah. Sehingga tak dipungkiri, bahwa semakin banyaknya skandaldan kegagalan audit yang terjadi menunjukkan pemahaman atas sikap integritas hanya sebatas teori kulit saja. Adanya faktor pragmatisme bisnis yang mendominasi dan menyebabkan akuntan publik terfokus pada sisi materialitas dan kapitalis.

\section{DAFTAR PUSTAKA}

Azis, N. A., Y. Mangoting dan N. Q. Lutfillah. 2015. "Memaknai Independensi Auditor dengan Keindahan Nilai-Nilai Kearifan Lokal Siri' Na Pacce". Jurnal Akuntansi Multiparadigma. Vol. 6 No. 1. pp. 145-156.

Cresswell, J. W. 1998. Qualitative Inquiry and Research Design: Choosing Among Five Traditions. Sage Publication Inc. USA.

Cresswell, J. W. 2013. Research Design Pendekatan Kualitatif, Kuantitatif, dan Mixed. Edisi ketiga. Pustaka Pelajar. Yogyakarta.

Fearnley, S., V. Beattie dan R. Brandt. 2005. "Auditor independence and audit risk: a reconceptualisation". Journal of International Accounting Research. Vol. 4 No. 1. pp. 39-71.

Jackling, B., B. J. Cooper, P. Leung dan S. Dellaportas. 2007. "Professional accounting bodies' perceptions of ethical issues, causes of ethical failure and ethics education". Managerial Auditing Journal. Vol. 22 No. 9. pp. 928-944.

Kuswarno, E. 2009. Fenomenologi, Konsepsi, Pedoman dan Contoh Penelitian. Widya Padjadjaran. Bandung.

McPhail, K. dan D. Walters. 2009. Accounting \& Business Ethics. Routledge. New York.

Mulyana, D. 2001. Metodologi Penelitian Kualitatif Paradigma Baru Ilmu Komunikasi dan Ilmu Sosial Lainnya. Remaja Rosdakarya. Bandung. 
Memaknai

Sikap

Integritas...
Nadirsyah dan R. Malahayati. 2007. "Pengaruh Perilaku Etis, Tekanan Ketaatan dan Pengalaman Auditor Terhadap Pengambilan Keputusan Etis Auditor (Studi Empiris pada Auditor BPKP NAD)". Wafa. Vol. 2 No. 2.

Nasirwan. 2011. "Telaah pelanggaran terhadap etika profesi akuntan: metode hermeneutik". Jurnal Keuangan \& Bisnis. Vol. 3 No. 1. pp. 49-55.

1002 